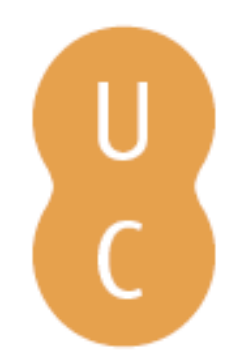

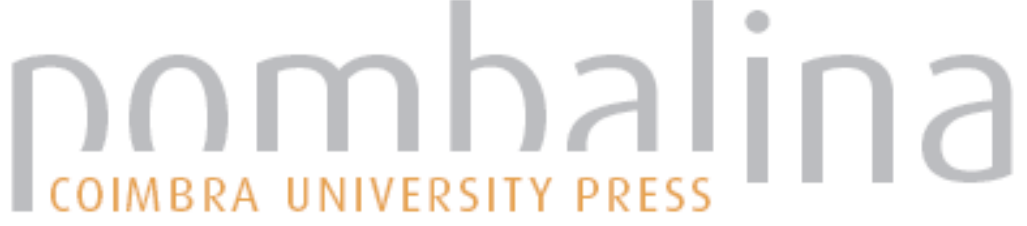

\section{Plutarco no humanismo Renascentista em Portugal}

\author{
Autor(es): $\quad$ Soares, Nair de Nazaré Castro \\ Publicado por: Imprensa da Universidade de Coimbra \\ URL \\ persistente: URI:http://hdl.handle.net/10316.2/30741 \\ DOI: $\quad$ DOI:http://dx.doi.org/10.14195/978-989-8281-94-4_1
}

Accessed : $\quad$ 26-Apr-2023 10:12:48

A navegação consulta e descarregamento dos títulos inseridos nas Bibliotecas Digitais UC Digitalis, UC Pombalina e UC Impactum, pressupõem a aceitação plena e sem reservas dos Termos e Condições de Uso destas Bibliotecas Digitais, disponíveis em https://digitalis.uc.pt/pt-pt/termos.

Conforme exposto nos referidos Termos e Condições de Uso, o descarregamento de títulos de acesso restrito requer uma licença válida de autorização devendo o utilizador aceder ao(s) documento(s) a partir de um endereço de IP da instituição detentora da supramencionada licença.

Ao utilizador é apenas permitido o descarregamento para uso pessoal, pelo que o emprego do(s) título(s) descarregado(s) para outro fim, designadamente comercial, carece de autorização do respetivo autor ou editor da obra.

Na medida em que todas as obras da UC Digitalis se encontram protegidas pelo Código do Direito de Autor e Direitos Conexos e demais legislação aplicável, toda a cópia, parcial ou total, deste documento, nos casos em que é legalmente admitida, deverá conter ou fazer-se acompanhar por este aviso. 


\section{Joaquim Pinheiro José Ribeiro Ferreira Nair Castro Soares Rita Marnoto}

\section{Caminhos de Plutarco na EUROPA}

$2^{a}$ EDIÇÃo REVISTA E AUMENTADA 


\section{Plutarco no humanismo RenasCentista em PORTUgal}

Nair de Nazaré Castro Soares (Universidade de Coimbra)

Socrates Philosophiam e coelis deduxit in terras, Plutarchus introduxit in cubiculum, in conclaue, in thalamos singulorum. Erasmo $^{1}$

Jacqueline de Romilly, com a agudeza e a sensibilidade que póe em todos os seus trabalhos, dedica dois importantes capítulos a Plutarco, na sua obra $L a$ douceur dans la pensée grecque, ${ }^{2}$ onde afirma: «Vers la fin de la grande littérature grecque, on trouve, avec Plutarque, l'apogée de la notion de douceur. Chez lui, elle est partout; elle commande tout; et elle s'épanouit comme l'immage même d'un idéal de vie essentiellement grec». ${ }^{3}$

$\mathrm{O}$ próprio vocabulário da douceur - termo que exprime a qualidade humana de cada situação - é mais rico e mais completo do que em qualquer outro escritor, grego ou romano. ${ }^{4}$

${ }^{1}$ Erasmo 1961-1962: IV, 57-58.

2 J. de Romilly 1979: 275-307 (chap. XVI e XVII: «Plutarque et la douceur des héros»; «Plutarque et la douceur des sages»).

${ }^{3}$ Ibidem: 275. E prossegue a eminente professora (p. 292): «...la douceur évoquée par Plutarque s'inspire en certains cas de modèles [...]. Entre tous ces modèles, Plutarque choisit selon les circonstances; et leur combinaison même relève d'un mérite qu'aucun des auteurs précédents n'avait possédé - à savoir la finesse dans l'analyse psychologique».

${ }^{4}$ Ibidem: 274. É esta a conclusão a que chega, após o confronto que faz dos Moralia e das Vitae Parallelae de Plutarco com as obras 
Diversos, com efeito, são os estudos que analisam os termos, recorrentes na obra de Plutarco, que exprimem esta noção. Entre eles, surge frequentemente o de philanthrôpia, que se define como a virtude por excelência do homem civilizado e bem educado. ${ }^{5}$

Essência do movimento humanista, a humanitas - ponto de encontro entre tradição clássica e tradição cristã - abarca os conceitos de humanitas como sympátheia, de humanitas como pietas, de humanitas como charitas hominum, que não são mais do que variaçóes do conceito grego de philanthropia. ${ }^{6}$

Se não é possível encontrar no Renascimento qualquer doutrina filosófica comum, como observa Paul

de autores gregos e romanos, designadamente Platão, Aristóteles, Isócrates, Xenofonte, Cícero e Séneca. Este último tem tratados sobre os mesmos temas com os mesmos títulos, como é o caso do De ira e do De tranquilitate animi.

5 Ibidem: 274-307. Sobre a noção de philantrôpia - que ultrapassa o âmbito dos autores da Antiguidade greco-latina - nos autores cristãos, cf. Ibidem, «Douceur païenne et bonté chrétienne. I. La révolution du Christianisme».

${ }^{6}$ Ilustrativa, neste sentido, é a expressão de Guarino de Verona: Humanitas dicitur doctrina et erudicio unde vocantur studia humanitatis pro illa affectione quam habemus erga homines, quam Graeci uocant philanthropia, apud Gioacchino Paparelli (1973), Feritas, humanitas, diuinitas. L'essenza umanistica del Rinascimento, Napoli: 129. Paparelli demonstra (no cap. IX, p. 115-129), como os conceitos de doctrina e philanthrôpia se encontram intimamente ligados, na definição dos studia humanitatis, desde Petrarca e os humanistas do Quattrocento - Guarino de Verona, Leon Battista Alberti, Enea Silvio Piccolomini - aos primeiros humanistas europeus de Quinhentos, e entre eles Erasmo, fervoroso seguidor de Plutarco. 
Oskar Kristeller, ${ }^{7}$ premissa essencial de toda a cultura humanística, assente no aristotelismo ético-político e no designado «socratismo cristão», é que «o homem nasce para ser útil ao outro homem», ${ }^{8}$ pelo que o desenvolvimento dos dotes da ratio e do uerbum, que os distinguem dos outros animais, tem um alcance social. Os studia humanitatis são assim colocados ao serviço da "vita civile», em profunda implicação entre doctrina e societas. ${ }^{9}$

Não sem razão, Plutarco está entre os autores gregos que mais interesse despertaram no Renascimento. Houve já quem afirmasse que Cícero, Séneca, Plutarco preenchiam, no essencial, o quadro de uma humanitas orientada no sentido da vida social, ou melhor, de uma humanitas destinada a torna-se humanitas christiana. ${ }^{10}$

Considerado pelos humanistas desde Poliziano e Marsilio Ficino, a Erasmo e Fr. Luís de Granada como um moralista capaz de fazer a síntese entre a filosofia moral pagã e o verdadeiro cristianismo, ${ }^{11}$ foi assinalável

7 P. O. Kristeller 1955: 22. Em seu entender, o Humanismo da Renascimento, movimento cultural e literário, que na sua substância não era filosófico, teve importantes implicaçóes e consequências filosóficas, directamente relacionadas com o seu fundamental classicismo, que modelou o pensamento da época, em todos os domínios do conhecimento. Entre os autores da Antiguidade Clássica que considera favoritos do Humanismo Renascentista, conta-se Plutarco (cf. ibidem, e. g. p. 18 e 21).

${ }^{8}$ Vide e. g. Leon Battista Alberti 1843-1849: III. 92.

9 Sobre o empenhamento cívico do primeiro humanismo italiano e, na sua peugada, do movimento humanista europeu, vide e. g. J. Benthley 1987: 196-197 (maxime); P. Burke 1987 3a ed.

${ }^{10}$ Cf. O. Schottenloher 1972: II, 667-690 (maxime 684).

${ }^{11}$ Frei Luís de Granada refere-o explicitamente, no prefácio 
a influência de Plutarco no movimento geral das ideias renascentista.

O Humanismo, que se centra no saber e nos valores da Antiguidade apoiados nos textos originais dos seus autores, criteriosamente depurados e estabelecidos pela rigorosa filologia, vai conhecer e apreciar Plutarco, nos seus escritos morais, nos Moralia, de grande variedade e amplitude temática, e nas Vitae Parallelae, as suas biografias de homens ilustres, gregos e romanos, sobre os quais estabelece o páragon.

Conhecido na Idade Média através do tratado pseudo-plutarquiano Institutio Trajani, ${ }^{12}$ e redescoberto, na sua obra completa, nos finais do Trecento, ${ }^{13}$ é sobretudo a partir do século XV que o escritor de Queroneia vai merecer ediçốes e traduçóes latinas da autoria de humanistas de renome, e nas diferentes línguas vulgares, nos quatro cantos da Europa culta. ${ }^{14}$

da sua Collectanea moralis philosophiae (Olyssipone, 1571). Na sua Ecclesiasticae rhetoricae siue de ratione concionandi libri sex (Olyssipone, 1576) aduz os testemunhos de insignes autores e, em primeiro lugar, «Plutarco, o mais grave de todos os filósofos». Cf. trad. espanhola: L. De Granada 1945: III, 494.

${ }^{12}$ Esta obra - que segundo a tradição é o resultado do magistério de Plutarco junto do imperador Trajano -, encontrada no século XII, apresenta a orgânica do estado da Antiguidade, com um ténue revestimento cristáo, e aponta no sentido da secularização. Cita-a Frei António de Beja, na sua Breve Doutrina e ensinança de príncipes, através de Vincent de Beauveais. Vide a este propósito, Nair N. Castro Soares 1994: 60 e 68.

${ }^{13}$ Vide August Buck 1980: 157 e sqq.

${ }_{14}$ Entre os tradutores de grego para latim, encontram-se humanistas famosos como Guarino de Verona, Francesco Barbaro, Leonardo Bruni, Francesco Filelfo, Coluccio Salutati, Bartolomeo Platina, Angelo Decembrio, Niccolò Perotti, Desidério Erasmo. 
Entre estas, dadas as afinidades culturais e políticas de Portugal e Castela, merecem especial relevo as traduçóes castelhanas quatrocentistas de Alonso de Palencia e Carlos de Aragón, príncipe de Viana e, no século XVI, as de Diego Gracián de Alderete. ${ }^{15}$

Plutarco foi um dos autores mais frequentemente traduzidos e editados, mais lidos e imitados no Renascimento. ${ }^{16}$ A Guarino de Verona se deve a tradução do tratado pseudo-plutarquiano, o Peri paídôn agôgês, conhecido pelo título latino De liberis educandis, com importância marcante na divulgação da moderna pedagogia humanista - a ponto de ser considerado conjuntamente com a obra de Quintiliano verdadeiro vademecum de todos os escritores pedagógicos do Renascimento. ${ }^{17}$

Em línguas vulgares, além das traduçôes para castelhano, refiram-se as traduçóes de Pedro Crinito para italiano, de Thomas Elyot e Thomas North para inglês, de Jacques Amyot para francês, entre os principais. Sobre as traduçôes das obras de Plutarco, vide Nair N. Castro Soares 1994: 86; 87; 90; 92-93; 100; 112; 115; 116; 122; $143 ; 145 ; 149 ; 160 ; 167 ; 226-228 ; 237$.

${ }^{15}$ Alonso de Palencia (1423-1492) foi pajem de D. Alonso de Cartagena e de Bessarión, em Itália, onde estudou grego com Jorge Trebizonda. D. Alonso de Cartagena, futuro bispo de Burgos, traduziu o primeiro livro do De inuentione de Cícero para o nosso rei D. Duarte e foi diplomata em Portugal de 1421-1427. Vide a este propósito, Nair N. Castro Soares 1994: 90.

${ }_{16}$ Vide V. R. Giustiniani 1961: 3-62; R. Aulotte 1965. Augustin Redondo (1976: 623) refere Plutarco como «l'auteur peut-être le plus lu au XVI ${ }^{e}$. siècle»; e P. O. Kristeller (1955: 18 e 21) considera-o um dos autores favoritos do Renascimento.

${ }^{17}$ Sáo estas as palavras de G. B. Gerini 1896: 274: «Tra le molteplici operette di Plutarco, tradotte dal Guarino, è notevole l'opuscolo Intorno all'educazione dei fanciulli, che fece latino fra il 1410 ed il 1411, dedicandolo ad Angelo Corbinelli, il quale scritto, 
Plutarco foi objecto de grande apreço e efusivos louvores. São reveladoras, neste sentido, as palavras de Rabelais, quando apresenta Gargântua, na célebre carta a Pantagruel, a deleitar-se com a leitura dos diálogos de Platão e "les Moraulx de Plutarche" e a recomendá-la a seu filho. ${ }^{18}$

A mensagem espiritualizada de Plutarco, posta ao serviço da moral natural e do relacionamento, em termos afectivos, entre os membros de uma comunidade, encontra-se na Utopia de Thomas More. Os seus habitantes, leitores de Plutarco, tinham uma constituição modelada pelas leis de Licurgo, em Esparta, e adoravam uma deusa, Mytra - o nome de Mytra amplifica o sentido misterioso e sobrenatural do ser divino - aparentada com a divindade persa referida por Plutarco em De Iside et Osiride. ${ }^{19}$

Guillaume Budé modela a sua Institution $d u$ prince sobre os Apophtegmata de Plutarco. ${ }^{20}$

Frei António de Guevara, no Relox de principes - editado em Lisboa em 1529 por Germáo Galhardo, com privilégio de D. João III, segue Plutarco como principal fonte. ${ }^{21}$

António de Nebrija, em De liberis educandis, Thomas Elyot, em The governour, Jacopo Sadoleto, em De liberis recte instituendis, dão testemunho da

unitamente all'opera di Quintiliano, divenne il vademecum di tutti gli scrittori pedagogici del Rinascimento»

${ }^{18}$ François Rabelais 1959: 42.

${ }^{19}$ André Prévost 1978: 119-120; 541; 590; 613 e 715-716.

${ }^{20}$ Cf. Claude Bontems et alii 1965: 9-10.

${ }^{21}$ Augustin Redondo 1976: 545. 
presença constante de Plutarco, modelo pedagógico do humanismo europeu - o "Educador da Europa". ${ }^{22}$

Montaigne saúda nestes termos a tradução das Oeuvres morales de Plutarco, que Amyot acabava de publicar (Essais, II, 4): «... mais surtout je lui sais bon gré d' avoir su trier et choisir um livre si digne et si à propos, pour en faire présent à son pays. Nous autres ignorants étions perdus, si ce livre ne nous eût relevés du bourbier: sa merci (grâce à lui) nous osons à cette heure et parler et écrire; les dames en régentent les maîtres d'école; c' est notre bréviaire». ${ }^{23}$

Encarregado da educação dos dois últimos príncipes Valois, ${ }^{24}$ Amyot traduziu em 1559, com dedicatória a Henrique II, as Vies des hommes illustres e em 1572 as Oeuvres morales que dedica a Carlos IX. A Amyot e à lição de Plutarco se deve a reputação de ter sido este rei educado "fort catholiquement", assim como a do seu "bon, orné et éloquent parler". ${ }^{25}$

É contudo Erasmo, entre todos os autores desta época, aquele cuja obra reflecte de forma mais profunda, temática e formalmente, a lição do autor de Queroneia. É que aos muitos escritos de Erasmo - além da preocupação moral de fornecer modelos de conduta

${ }^{22}$ Vide Elio Antonio de Nebrija 1981 (ed.); Thomas Elyot 1880 (ed.); Jacopo Sadoleto 1855 (ed.).

${ }^{23}$ Cf. Pierre Villey 1912: 13-14.

${ }^{24}$ Vide A. Adler 1975: 131-138.

${ }^{25}$ Vide Ferdinand Buisson 1887: 2435-2436. Para se fazer uma ideia do empenho dos humanistas pela obra de Plutarco, pode consultar-se a bibliografia apresentada por Robert Aulotte 1971: 243-245. 
ao homem comum e ao homem de estado - preside também o ideal pedagógico-didáctico da formação integral do homem, na sua dimensão humana, espiritual e metafísica, numa permeabilidade intrínseca entre studia humanitatis e studia diuinitatis. Elucidativas, neste sentido, são estas palavras do Humanista de Roterdão: Bonae litterae reddunt homines; philosophia plusquam homines; theologia reddit diuos. ${ }^{26}$

Erasmo não se cansa de proclamar a grandeza do moralista grego, com quem profundamente se identifica, nos interesses comuns, nas ideias pedagógicas, éticopolíticas, de moral individual e social, na sensibilidade e gostos estéticos afins.

A expressão do apreço de Erasmo por Plutarco - a par da confessada dívida em relação à sua obra - surge a cada passo, a abrir os Adagia, os Apophthegmata, e na Institutio principis christiani. Nesta obra, o humanista de Roterdão coloca Plutarco em primeiro lugar, entre os autores clássicos que aconselha ao príncipe, não só pelos ensinamentos dos seus tratados - nada pode existir de mais santo - como pelo exemplo da sua vida. ${ }^{27}$

Compreende-se assim que Plutarco, a par de Quintiliano - logo seguidos de Diógenes Laércio - seja também a principal fonte do tratado de Erasmo que se destina à educação da primeira infância, o De pueris instituendis, ${ }^{28}$ cuja recepção é enorme em toda a Europa.

${ }^{26}$ Erasmo: L.B., IV, 628 D.

${ }^{27}$ Erasmo: L.B., IV, 587 F. Vide também a este propósito, Pierre Mesnard 1977: 97.

${ }^{28}$ Vide J.-C. Margolin 1966: 96-100. 
É na obra de Plutarco e na de Diógenes Laércio, editadas por vezes conjuntamente ${ }^{29}-$ sem esquecer as de Suetónio, Aulo Gélio ou Valério Máximo - que os humanistas, satisfazem o interesse pela Antiguidade, pelo pulsar concreto da vida das grandes figuras históricas, pela profundidade do seu pensamento, e colhem os exempla que enriquecem a sua inventio. ${ }^{30}$

Em Portugal, com a introdução do Humanismo, nos finais do século XV, designadamente a partir de Cataldo Parísio Sículo, que chega à corte de D. João II em 1485, Plutarco faz parte do corpus auctorum, lido e assimilado pelos nossos humanistas e integra a cultura literária dos nossos escritores da época de Quinhentos.

Já antes, num proto-humanismo liderado pelos Príncipes de Avis, a lição de Plutarco se fizera sentir, entre nós, por influência dos autores do Quattrocento italiano. ${ }^{31}$

${ }^{29}$ Vide a edição conjunta de escritos de Plutarco e Diógenes Laércio na B.N. Paris (cota: Z. 17588): Apophthegmata graeca regum et ducum, philosophorum item aliorumque... ex Plutarco et Diogene Laertio. Cum latina interpretatione. Loci aliquot in graeco contextu emendati fuerunt... . s. 1., H. Stephanus, 1568.

30 Sobre o interesse das obras de carácter biográfico no Renascimento, P. O. Kristeller (1962: 392) pronuncia-se, nestes termos: «Nel campo letterario, la letteratura biografica e quella autobiografica ebbero una fioritura raramente raggiunta in altre epoche».

31 Se é possível aludir a um proto-humanismo na corte de Avis, a influência humanista é bem mais notória do ponto de vista ideológico do que do ponto de vista estético-filológico, onde haveria ainda largo caminho a percorrer. Pier Paolo Vergerio, que sabia grego e tivera Manuel Crisolara por primeiro mestre, recolhe, na sua obra 
A preferência por Plutarco reflecte-se já na obra de Vasco de Lucena, um português ao serviço da duquesa Isabel, filha de D. João I, na corte de Borgonha do século XV, com estreitas relaçôes com o humanismo italiano, a que também nós não fomos alheios. A Vasco de Lucena se deve a Histoire d'Alexandre de Quinto Cúrcio, completada nas lacunas do original sobretudo pela Vida de Alexandre de Plutarco, segundo a versão latina de Guarino de Verona. ${ }^{32}$

Expressiva, entre nós, é a tradução "em linguajem" - realizada por Vasco Fernandes de Lucena, na corte de Avis, a pedido do Infante D. Pedro -, do tratado pedagógico, com nítida influência de Plutarco, 'Sobre os nobres costumes e os estudos liberais da juventude', De ingenuis moribus et liberalibus studiis adulescentiae (1402). É este o primeiro tratado pedagógico, na verdadeira acepção da palavra, quer pelo teor prático da

pedagógica, os ensinamentos de Plutarco - do tratado pedagógico e das restantes Obras morais, bem como das Vidas Paralelas, de que cita a Vida de Mário. Sabe-se que a traduçáo latina de Guarino de Verona do De liberis educandis de Plutarco data de 1410, apesar de ter sido publicada em 1497. É conhecida, no entanto, a ampla divulgação, nesta época, dos originais manuscritos, por vezes com implicaçôes a nível de autoria, como é o caso da obra De regnandi peritia de Agostinho Nifo, inspirada no manuscrito de Il principe de Maquiavel). Sobre a importância de Plutarco no Quattrocento italiano, vide G. B. Gerini 1896; Eugenio Garin 1958: 307-503 e 725-726.

${ }^{32}$ Além de presente nas Vidas paralelas, a figura de Alexandre é ainda tema de dois opúsculos de Plutarco, que, dentro da tradiçấo retórica da declamação, discutem os conceitos de tyche e aretê, que se interpenetram e sobrepóem, sem verdadeiramente se oporem, no grande herói macedónio, como exemplum. Vide Nair N. Castro Soares 1994: 87; M. R. Cammarota 1992: 105-124; M. R. Cammarota 2000: 69-86; M. R. Cammarota 2002: 147-166. 
sua doutrina, quer pela real divulgação que conheceu em toda a Europa. ${ }^{33}$

$\mathrm{Na}$ verdade, de grande significado na definição dos nossos ideais culturais, nesta época, é a influência directa da Itália em Portugal, pelo menos a partir do início do século XIV. Conhecida é a presença de letrados portugueses em Itália entre 1350 e 1450 e o papel desempenhado pelo abade D. Gomes, geral da ordem camalduense, núncio e visitador apostólico dos mosteiros de Portugal, figura de grande prestígio em Florença. ${ }^{34} \mathrm{Na}$ abadia de D. Gomes, futuro prior de Santa Cruz de Coimbra, fora D. Pedro recebido por ocasião da sua visita a Itália. ${ }^{35}$

A importância que o livro de Vergério teve no Renascimento português advém-lhe não só da recepção

${ }^{33}$ Vide P. P. Vergerio 1918 (ed.). Nas suas viagens pelos centros políticos, culturais e religiosos da Europa (1425-1428) - Inglaterra, Flandres, Hungria, Itália (Veneza, Pádua, Florença e Roma) - o Infante D. Pedro relaciona-se com humanistas italianos, tais como Ambrogio Traversari, que lhe dedica a tradução do De Prouidentia de S. João Crisóstomo, e com Pier Paolo Vergerio (1370-1444), que conheceu na corte de Segismundo da Hungria. $\mathrm{O}$ tradutor deste tratado, Vasco Fernandes de Lucena - distinto de Vasco de Lucena, anteriormente referido - foi um dos tradutores mais activos dos autores clássicos, ao serviço dos ideais pedagógicos dos príncipes de Avis. Desempenhou ainda funçóes de embaixador do rei D. Duarte (ao Concílio de Basileia e junto do Papa Eugénio IV) e do rei D. João II (junto do papa Inocêncio VII).

${ }^{34}$ Vide Davide Bigalli 1989: 65-117.

35 O Infante D. Pedro, nas suas viagens pela Europa (14241428) - Inglaterra, Flandres, Hungria, Itália (Veneza, Pádua, Florença e Roma) - relaciona-se com humanistas italianos, tais como Ambrogio Traversari - que lhe dedica a tradução do De Prouidentia de S. João Crisóstomo - e Pier Paolo Vergerio (13701444), que conheceu na corte de Segismundo da Hungria. 
que teve entre nós, a partir do século XV, mas sobretudo do facto de definir os ideais e o programa da educação humanística. ${ }^{36}$ Dedicado a Ubertino de Carrara, este tratado destinava-se à educação de jovens pertencentes a famílias principescas ou nobres. O ideal de renovação do espírito de Roma presidiu à elaboração desta obra, em que sobressai a inspiração dos clássicos, Cícero e Séneca e os recém redescobertos Quintiliano e Plutarco - intérprete este do pensamento grego dos autores do século IV e da filosofia da época helenística, com admirável sincretismo. ${ }^{37}$

A partir da obra de Vergerio, a influência de Plutarco está amplamente documentada em toda a tratadística pedagógica, de inspiração clássica, designada por educação moderna, desde os autores do Quattrocento, como Maffeo Vegio (De educatione liberorum clarisque eorum moribus), Enea Silvio Piccolomini (De educatione liberorum), Leon Battista Alberti (Della famiglia), Francesco Filelfo (De morali disciplina), Diomede Carafa (Dello optimo cortesano), entre outros. Carafa precede e anuncia Il Cortegiano de Baldassare Castiglione e Il Galateo de um Giovanni della Casa, autores que, no

${ }^{36}$ Vide, maxime, os caps. 26-32 do De ingenuis moribus.

37 Os princípios ético-pedagógicos, que desde a sofística e a partir de então, designadamente em Isócrates, Xenofonte, Platão, Aristóteles, o educador de Alexandre, aos autores latinos, e entre eles Cícero - fonte de informação das várias escolas de filosofia grega e modelo humanista de pensamento ecléctico, em que se harmonizam eloquência e sabedoria - serviram de referência a Plutarco bem como a Quintiliano e aos autores da Segunda Sofística, com seus ideais pedagógicos predominantes. Vide G. Anderson 1993. 
século XVI, se ocuparam da arte e da ciência do bem viver cortesanesco, dentro de uma ética que Plutarco actualizara, a partir da famosa edição aldina dos Moralia, no original grego, intitulada Opuscula (1509). É esta a edição de que se serve Erasmo para elaborar a tradução latina froebeniana (em 1514) e a que sairia a lume, mais completa, nos prelos venezianos dos herdeiros de Aldo Manúcio (em 1518) - que no ano seguinte editariam, no original grego, as Vitae parallelae. ${ }^{38}$

Marco definitivo da orientação das ideias pedagógicas da educação moderna são os ensinamentos do De liberis educandis, que abre os Moralia, sobre a criação, instrução e formação dos filhos, desde a sua concepçáo à sua emancipação, quando contraem casamento, verdadeiros topoi nos tratados humanistas ${ }^{39}$.

Plutarco, defensor e representante de uma moral social nova, contesta valores da cultura grega como a pederastia e a homossexualidade e vai colocar, como centro do casamento, o amor conjugal, de que faz depender a feliz convivência entre os esposos, a condição

${ }^{38} \mathrm{O}$ Perì Paídôn agôgếs, traduzido em latim pela primeira vez em finais do século XV por Guarino de Verona, conhece uma ediçáo conjunta (Paris, 1454) com o De ingenuis moribus de Pier Paolo Vergério: B.N. Paris - cota: /Rés. R. 1566. Em Veneza, os prelos de Aldo Manúcio (1494-1515) e seus herdeiros vão conhecer um notável labor editorial, com a supervisão de humanistas como Erasmo, que neles publica os seus célebres Opera, em 1518.

39 Outros opúsculos, com ensinamentos importantes para a educação e formação do carácter, e fonte de inspiração frequente dos humanistas, são: o De audiendo, ou De recta ratione audiendi, o De audiendis poetis e o De musica. Além de escritos como An uirtus doceri possit, De uirtute morali, De uirtute et uitio, De uitioso pudore, que se adequam admiravelmente à mundividência humanista. 
da mulher face ao marido. ${ }^{40}$ É este um dos aspectos mais marcantes da modernidade do pensamento de Plutarco, nos Moralia: a importância concedida à instituição do casamento, à reciprocidade de deveres dos cônjuges, à família, pais e filhos, em que se assume como princípio universal a afectividade, a comprensão, a doçura semelhante à caritas Paulina -, do maior alcance no relacionamento mútuo e na educação dos filhos. ${ }^{41}$

Já no Leal Conselheiro, da primeira metade do século XV, D. Duarte dedica alguns capítulos à reflexão sobre o amor e o casamento. Além da sua experiência pessoal - o mais interessante desta obra - não faltaram ao monarca referências literárias. ${ }^{42}$ Não poderemos deixar de lembrar que o De regimine principum de Egídio Romano, que fazia parte da biblioteca real e era

${ }^{40}$ Expressivos são os opúsculos de Plutarco, como: Coniugalia praecepta, Mulierum uitutes, Amatorius, Amatoriae narrationes, De amore prolis, Consolatio ad uxorem, De fraterno amore.

${ }^{41}$ Entre as obras de Plutarco que abordam mais directamente esta matéria refiram-se - em tradução latina, veículo privilegiado da sua divulgação, no Renascimento - Amatorius, onde enaltece a importância do amor conjugal; os Coniugalia praecepta, conselhos sobre a vida conjugal, dirigidos a dois dos seus discípulos que vão casar, Eurídice e Poliano; a Consolatio ad uxorem, por ocasião da morte de uma filha, em que alia a serenidade filosófica a uma singular ternura pela esposa; o De amore prolis e o De liberis educandis, em que os filhos são o principal objecto; e, enfim, sobre o amor fraternal, o De fraterno amore. Isto sem esquecer muitas das suas Vitae, que apresentam exemplos históricos dos valores enunciados nos Moralia.

${ }^{42}$ Cf. os capítulos RIIII-RVIII. Vide Mário Martins: 1983: 187206; Paulette Demerson 1983: 483-500; M. Lurdes C. Fernandes 1984: 133-194. 
obra de leitura privilegiada na corte de Avis, se debruça no Livro II sobre a família: a primeira parte sobre a vida matrimonial e a segunda sobre a educação dos filhos.

Durante a Idade Média, descuraram-se as virtudes naturais e espirituais da união conjugal, pôs-se em causa a legitimidade do casamento como sacramento, considerado benéfico no plano moral e social, mas bem inferior ao estado religioso, à vida monástica. ${ }^{43}$

A consolidação progressiva da autoridade do estado, sobretudo a partir do séc. XV, e as perturbaçóes ocasionadas pela importância conferida ao poder económico como factor de ascenção social contribuíram para a revalorização do casamento e da família, célula de base da sociedade. Face a uma economia em expansão, em que o dinheiro desempenha um papel primordial, impóe-se o regresso aos valores tradicionais, à dignificação do casamento, ao fortalecimento dos laços familiares, sem os quais a ordem social não pode ser mantida. Exemplos significativos desta atitude são os tratados do Quattrocento italiano, profundamente influenciados pela obra de Plutarco: o De re uxoria de Francesco Barbaro, composto em 1415-1416, e sobretudo Della famiglia, de Leon Battista Alberti, de cerca de 1440 , que teve grande e rápida divulgação, a julgar pela influência que teria tido na Celestina. ${ }^{44}$

É no século XVI que ganha actualidade a problemática do casamento (An sit nubendum?), que constitui um dos debates favoritos das escolas dos

\footnotetext{
${ }^{43}$ Lucien Febvre 1944: 314; Émile V. Telle 1954: 409-410.

${ }^{44}$ Vide Marcel Bataillon 1961; J. A. Maravall 1964.
} 
sofistas, que surge no Organon de Aristóteles, nos livros das Categoriae uel praedicamenta - sob as espécies do último modo do praedicamentum "De habere» - e figura como exemplum nos Progymnasmata de Hermógenes e de Aftónio, muito divulgados e apreciados, no Renascimento. ${ }^{45}$

Tema eterno, pelas suas implicaçóes múltipas no domínio do humano, o casamento tornou-se um dos assuntos mais vezes abordado pelos homens de Quinhentos. Neste sentido, reveste-se de particular importância a obra de Erasmo que, sobretudo a partir do Enchiridion militis christiani, muito contribui para a secularização da piedade cristã e consequentemente do estado matrimonial. ${ }^{46}$ Diversas são as obras em que o Humanista de Roterdáo aborda o tema do casamento, designadamente o Encomium matrimonii, de 1518, os Colloquia matrimoniais, que datam de 1523 - os que apresentam ensinamentos pré-nupciais, Virgo misogamos, Virgo poenitens, Proci et Puella e o célebre Uxor mempsigamos siue coniugium, que contém instruçốes para os esposos - e a Institutio christiani matrimonii de 1526.

45 Vide Gérard Defaux 1973): 212-214. Assinalável é a importância de que se revestem os Progymnasmata, no ensino da retórica e da diléctica, e na construçáo do discurso dos autores do Renascimento. Basta lembrar Rudolfo Agricola - tradutor dos Progymnasmata de Aftónio - Erasmo, ou Guillaume Budé, ilustres humanistas do primeiro humanismo europeu, influenciados pela tradição patrística e bizantina. Vide R. Naudeau 1952: 264-285; Lisa Jardine 1988: 38-57 (em especial p. 48 e sqq.); J. Chomarat 1981: 520; A. Michel 1984: 19-29; J. Ijsewijn 1973: 329-342.

${ }^{46}$ Vide Marcel Bataillon 1966: 287. 
Além da produção erasmiana, que difundiu e vulgarizou um paulinismo matrimonial que actualiza a mensagem de Plutarco, outras obras de diferentes autores se lhe seguiram. Lembre-se, entre os mais célebres, Luís Vives com os seus tratados De institutione foeminae christianae, de 1523 , e De officio mariti, de 1529.

Muitas foram as traduçóes e adaptaçóes destas obras - por exemplo, na vizinha Espanha - ou que delas receberam influência. ${ }^{47}$

Por toda a Europa, onde era alarmante o número de filhos naturais e de casamentos clandestinos, se generaliza o gosto por esta literatura sobre o casamento, no seu aspecto teológico, jurídico, institucional e humano, inspirada na Sagrada Escritura, no direito romano - o romanismo impóe-se como esteio da secularização -, nos tratados clássicos de economia doméstica de Aristóteles e de Xenofonte e nos preceitos matrimoniais de Plutarco. ${ }^{48}$

${ }^{47}$ Exemplo da recepção destas obras é o Relox de príncipes de Fr. Antonio de Guevara. Vide Augustin Redondo 1976: 623-624.

Entre as traduçóes castelhanas de Erasmo contam-se o Colloquio de Erasmo intitulado Institución del matrimonio christiano de Diego Moejón (1527), versão do Colóquio erasmiano Uxor mempsigamos; e o Sermón en loor del matrimonio, de Juan de Molina, composto a partir do Encomium matrimonii (1528).

O tratado de Vives De institutione foeminae christianae é traduzido por Juan Justiniano, com o título Libro llamado Institución de la muger christiana (1528).

${ }^{48}$ Vide L. Guillerm, Jean Pierre Guillerm et alii (1983), Le miroir des femmes I. Moralistes et polémistes au XVIe siècle. Lille. Entre todas são de referir as obras de Tiraqueau, De legibus Connubialibus (desde 1513), de Nevizano, Sylvia nuptialis (1521), as de H.-C. 
O casamento foi tema de debate alargado, desde a primeira metade do século XVI, ${ }^{49}$ até aos seus finais, em tempos da Contra-Reforma, de que são exemplo os diálogos filosóficos sobre a vida civil de G. B. Giraldi Cinzio - que integram os Ecatommiti, as cem novelas que serviram de fonte de inspiração a Shakespeare que mereceram tradução francesa de Gabriel Chappuys (Paris, 1583). ${ }^{50}$ Sobre os Diálogos de Cinzio dirá J. P. Guillerm: «Seul Giraldi, sous le couvert d'une réunion élégante, s'efforce dans le contexte post-tridentin de proposer un moralisme tout imprégné de la sagesse d'un Plutarque». ${ }^{51}$

Em Portugal, inserem-se nesta tendência moralizadora o Espelho de casados do Doutor Joáo de Barros, o Casamento perfeito de Diogo Paiva de Andrade, e o tratado - a que acresce a componente jurídica - Dos priuilegios \& praerogatiuas $\tilde{q}$ ho genero feminino tẽ de Rui Gonçalves. ${ }^{52}$

Agrippa de Nettessheim, De sacramento matrimonii (1526) e De nobilitate et praecellentia foeminei sexus (1529).

${ }^{49}$ É sobretudo a partir de 1520, data em que Lutero publicara O cativeiro babilónico da Igreja, que muitas obras se debruçaram sobre o sétimo sacramento. Vide Emile V. Telle 1954: 296

${ }^{50}$ Gabriel Chappuys 1583.

${ }^{51}$ Cf. L. Guillerm, Jean-Pierre Guillerm et alii 1983: 42. O próprio Concílio de Trento se pronunciou sobre a disciplina e a atéliturgia do casamento cristáo. Cf. Ibidem: 115-124, a tradução francesa quinhentista por Gabriel Du Préau dos Decretos e Cânones do Concílio de Trento, respeitantes ao casamento.

${ }^{52}$ Vide Espelho de casados pelo Doctor João de Barros (1540): 1874 (ed.); Diogo Paiva de Andrade (1630), Casamento perfeito em que se contem advertências... para viverem os casados em quietação... \& muitas hystorias, \& acontecimentos... dos tempos antigos, \& modernos... com 
Curioso é notar que o Espelho de casados do Doutor João de Barros reflecte os gostos retóricos da época e apresenta-se, formalmente, como um exemplo de debate An sit nubendum?

A primeira parte contém «Doze razóes que disfavorecem o casamento as quaes se poserom aqui pera se reprouarem: por mayor favor dele». Na segunda parte «o autor prova por Doze Razóes evidentes e muytos fundamentos quam excelente e proveitoso e necessário seja o casamento».

A temática do casamento, na nossa literatura, a exprimir a mentalidade do tempo, está presente nas obras de teatro - em alguns autos de Gil Vicente, nas comédias de Jorge Ferreira de Vasconcelos, nos autos de Camóes -, ou ainda mais explicitamente, porque repositório de preceitos, na Collectanea moralis philosophiae de Frei Luís de Granada. Neste livro de sentenças, a matéria apresenta-se seriada, segundo os diferentes temas - series locorum. ${ }^{53}$ Dividida em três partes, a segunda é dedicada aos opúsculos morais de

varias sentenças, \& documentos de autores gregos, \& latinos...Lisboa, Jorge Rodrigues; Rui Gonçalves, Dos priuilegios \& praerogatiuas $\tilde{q}$ o genero feminino tẽ por dereito comũ \& ordenaçôes do Reyno mais que ho genero masculino. Apud Iohanne Barrerium Regium Typographum, Anno Domini 1557.

${ }^{53}$ Vide Collectanea moralis philosophiae, in tres tomos distributa: quorum primus selectissimas sententias ex omnibus Senecae operibus, Secundus ex moralibus opusculis Plutarchi, Tertius clarissimorum principum \& philosophorum insigniora apophthegmata, hoc est, dicta memorabilia complectitur. Collectore F. Ludovico granateñ monacho Dominicano. Olisippone, Excudebat Franciscus Correa, Serenis S. Cardinalis Iff. Typogra. 1571. 
Plutarco, e estende-se por cerca de trezentas páginas (497-787).

Entre as reflexões, feitas no prefácio desta obra, que servem para enaltecer a grandeza moral da mensagem dos autores clássicos e encarecer a utilidade da sua leitura, surge o elogio de Plutarco, que termina nestes termos: «Nenhum destes erros se encontra em Plutarco, mas tudo nele está como que de acordo com a luz da razão e da natureza mais recta: talvez porque o Evangelho de Cristo, brilhando ao longe no século em que ele vivia, acrescentava ao espírito humano uma maior luz de verdade». ${ }^{54}$

$\mathrm{Na}$ segunda parte desta colectânea, dedicada à mensagem de Plutarco (p. 497-787), têm relevo temas como o casamento, o relacionamento entre os cônjuges, a educação dos filhos, ou outros respeitantes à moral individual ou social. ${ }^{55}$ A auctoritas de Plutarco e o

${ }^{54}$ Ibidem: Horum /errorum/ nibil in Plutarcho deprehendes: sed omnia fere purgatissimae rationi, et naturae lumini consentanea: fortasse quoniam Euangelio Christi eius seculo latius coruscante, maior humanis mentibus ueritatis lux addita esset.

${ }^{55}$ Vide e. g. Matrimonium (p. 518; 548); Viret uxor-Matrimonium (p. 518-520; 548); Pater, flius, filiorum educatio (p. 520-527); educatio filiorum (p. 520; 510; 715); Pater (p. 520; 613; 510); Adolescentia, senectus (p. 517); Obseruantia in maiores (p. 666); Verecundia siue pudor (p. 737); affectus et passiones animae (p. 514); Dilectio erga inimicos (p. 587, 600; 630); adulatio (632; 567; 586; 548; 609); Hipocrisis (p. 765); Beneuolentia ciuium captanda et maleuolentia fugienda (p. 621); Virtus quomodo facilis (p. 578); Hominis dignitas (p. 513); Quies siue tranquillitas animi (p. 725; 580). Note-se que todos estes loci apresentam a mensagem de Plutarco, colhida nas diferentes obras, pelo que os Moralia e as Vitae são aproveitados indistintamente. Assim, por exemplo, a educação dos filhos (p. 520-527) apoia-se sobretudo no De liberis educandis, mas em grande medida nos costumes dos Lacedemónios, veiculados pela vida de Licurgo. Na Collectanea se 
fácil acesso à sua mensagem equiparam esta obra, pelo menos junto de um público mais erudito, aos tratados especificamente compostos sobre o assunto, pese embora a divergente forma discursiva.

Todas estas obras, apesar de enfoques variados, apresentam, a nível da doutrinação ou da linguagem, das imagens e das sententiae, aspectos comuns que têm por fonte Plutarco. É que muitos dos preceitos e ideias que Plutarco defende são o resultado da serenidade filosófica do Sacerdote do templo de Delfos, da sua vivência de marido e pai de filhos.

$\mathrm{Na}$ base da afectividade familiar, pedra angular do seu edifício pedagógico se desenvolve toda a sua filosofia da educação, delineada nos praecepta do seu De liberis educandis e ao longo de toda a obra moral, em que à influência estóica, à diatribe cínica e aos lugares comuns da filosofia popular, se sobrepóe sempre a sua forma peculiar de encarar a vida, decorrente da sua experiência e das suas mais profundas convicçôes.

encontra também a recomendaçáo do aleitamento materno, que favorece a relação afectiva entre mãe e filho (p. 522): uinculo amorem beneuolentiamque fauerent. Este motivo surge na tratadística pedagógica desde o Quattrocento (e.g. De re uxoria de Ermolao Barbaro) e figura no De regis institutione et disciplina (1572) de D. Jerónimo Osório, dedicado a D. Sebastiáo. O famoso Bispo de Sives náo omite a censura - que remonta às Noctes Atticae de Aulo Gélio (12.1) - às rainhas que devem amamentar os filhos, pois a natureza as dotou de dois seios como aos outros animais. E acrescenta um pormenor realista: nem só as rainhas, mas quase todas as mulheres de boa família, preferem partilhar com outras mulheres o dulcíssimo nome de mãe. Responsáveis por isso são as deliciae atque perditi mores dos tempos actuais (Opera Omnia 1592: I. 374. 25-36). 
A nível dos princípios, dos fundamenta em que assenta a educação, Plutarco, ou pseudo-Plutarco, ${ }^{56}$ encarece neste opúsculo pedagógico, De liberis educandis, a importância da natureza, o aperfeiçoamento das tendências naturais pela criação de bons hábitos, que moldam o carácter, ${ }^{57}$ o papel da memória, ${ }^{58}$ a crença na virtude que pode ser ensinada, ${ }^{59} \mathrm{o}$ valor da emulação, o sentido da honra, a cultura da vergonha, com origens na poesia homérica; a importância do carácter do preceptor e a sua arte em estabelecer uma relação de respeito e afecto, em dosear os louvores e as censuras, em evitar a fadiga, em incentivar, nos discípulos, o amor

56 Os humanistas atribuíram a Plutarco este pequeno tratado e nunca puseram em causa a sua autoria, pelo que não tem grande significado para o estudo desta época a opinião da crítica moderna, que é praticamente unânime em considerá-lo pseudo-plutarquiano. Assim atribuiremos a Plutarco as ideias nele recolhidas. Sobre a questão da autenticidade do De liberis educandis, que foi pela primeira vez levantada no século XVII, vide Francesca Albini 1977: 69, n. 2.

${ }^{57}$ A importância da tríade educativa, natura (ingenium), ars, studium (exercitatio) remonta aos pré-socráticos e conhece grande divulgação entre os sofistas e sobretudo a partir deles, tornando-se um tópico discutido por todas as escólas filosóficas. Vide Platão, Men. 70 a sqq.; Phdr. 269 d; Prt. 323 d; Lg. 792 e; Aristóteles, Pol. 1332 a 38-40; 1337 a 1; EN. 1179 b 20-21; Rh. 1410 b 6-7; Xenofonte, Mem. 3. 9. 2; 2. 6. 39; 3. 3. 11; Isócrates, Paid. III; Lucrécio, De rer. nat. 3.319 sqq.

58 A arte da memória, prática pedagógica do Renascimento, teve como mais antiga fonte que se conhece o poeta grego do século VI a. C., Simónides de Céos - a quem se deve a definiçao de tão grande fortuna, "a pintura é poesia muda, a poesia imagem que fala”. Vide sobre o assunto F. A. Yates 1975; Michele Simondon 1982: 181-190 (maxime).

59 Plutarco desenvolve esta temática no opúsculo moral, conhecido pelo título latino, An virtus doceri possit. O problema do ensino da virtude é já posto no Ménon por Platão. 
aos estudos, em que é nítida a inspiração platónica. Esta porém está condicionada ao contexto histórico e social de Plutarco e ao ponto de vista por si adoptado, que se prende prioritariamente com os fundamentos da educação e da moral. ${ }^{60}$

Plutarco dirige-se prioritariamente aos pais e recomenda-lhes que se empenhem acima de tudo na criação, formação e educação de seus filhos. ${ }^{61} \mathrm{Os}$ dois progenitores devem ter, em parceria, um papel complementar. À mãe, desde os cuidados a ter com o nascimento dos filhos, cabe-lhe amamentá-los, num estreitamento da ligação entre ambos, prevenir-se contra uma educação amolecida e branda, enfraquecedora do carácter e desencadeadora da filautia, precaver-se do turpilóquio, preservar os filhos de más convivências. Plutarco recomenda ainda aos pais que, sem olhar a gastos, providenciem no sentido de dar a melhor educação a seus filhos, sem se esquecerem de que também já foram jovens, para suportarem, sem se indignarem, as faltas de seus filhos: tal como os médicos - o símile, de grande fortuna, é colhido em Lucrécio (4.11-16) devem misturar a doçura, a prâtês, com o amargor das correcções. ${ }^{62}$ Em suma, a educação integral, concebida

${ }^{60}$ Vide, a este propósito, Ana Esther Velázquez Fernández 1999: 501- 514 .

${ }^{61}$ Vide Francesca Albini 1977: 59-71. Para uma análise das ideias do De liberis educandis, vide Dominique Faure 1960: 18-22; cf ainda, sobre este tratado, na sua especificidade, e na sua relação com o pensamento platónico, o referido estudo de Ana Esther Velázquez Fernández 1999: 501- 514.

${ }^{62}$ Cf. De liberis educandis, 13 d. É este um dos aspectos mais expressivos da teorização de Plutarco, com marcas indeléveis na 
como um bem supremo, será a preocupação primeira dos pais que, acima de tudo, devem ser exemplo, paradigma para os filhos.

Estas observações sobre a puerilis institutio caracterizam a educaçáo moderna desde o Quattocento, desde as obras de Pier Paolo Vergerio e Francesco Patrizi Senense aos tratados pedagógicos de finais do século XVI. ${ }^{63}$

$\mathrm{Na}$ tratadística portuguesa, o Livro da Virtuosa benfeitoria do Infante D. Pedro é um documento, no Portugal quatrocentista, das ideias da pedagogia moderna, veiculadas pelo tratado de Pier Paolo Vergerio, que o nosso «Infante das sete partidas» conhecera em Itália. ${ }^{64}$

Alguns passos são por demais significativos do proto-humanismo da corte portuguesa do século XV, que indiciam a permeabilidade da mensagem clássica e do ideal pedagógico de Plutarco. A crença na natureza humana e na sua perfectibilidade, através do ensino e da educação, é um dos aspectos notórios da modernidade do seu pensamento; a própria metáfora da terra, que deve ser cultivada para dar bom fruto - que se encontra em

pedagogia humanista, por revelar uma nova atitude face à criança, um ser em formação e não um adulto em miniatura. A modernidade do pensamento de Plutarco, que está na base da futura psicologia diferencial, defendida pelos pedagogos humanistas desde o Quattrocento, foi aceite com excessivas reservas pelo italiano Cataldo Parísio Sículo, o introdutor do humanismo em Portugal e educador da nobreza portuguesa. vide Nair N. Castro Soares 2002a: 311-340, maxime 321-323.

${ }^{63}$ Vide Nair N. Castro Soares 1994: 97-188.

${ }^{64}$ Vide Nair N. Castro Soares 1993a: 289-314. 
Cícero e em Plutarco e informa o tratado pedagógico de Vergério - está presente no Livro da Virtuosa benfeitoria: «Portanto assi como boos lavradores, com trabalhos e adubios, vençamos a terra que he maninha». ${ }^{65}$

Se D. Pedro, neste tratado, não apresenta uma ratio studiorum, um plano de educação régia ou aristocrática, no entanto, é manifesto o seu intelectualismo socrático, a preocupação da ensinança, capaz de proporcionar a sabedoria, "que a muytos tyrou e tyra de mal fazer» como afirma na famosa "Carta de Bruges", documento indispensável para se ajuizar, em plenitude, do pensamento pedagógico do Infante. Dirá, na Virtuosa benfeitoria: «que os benefficios da benquerença non devem seer tirados aaquelles cuja saude speramos». ${ }^{66}$ "Os duros e cruevees façamos brandos e amolentemos». ${ }^{67}$ "E, ffalando com boa graça, dando conselhos e boas ensinanças aproveytaremos quaaesquer que podermos». ${ }^{68}$

O primeiro cuidado a ter com a educação deve-se aos pais, que dão aos filhos "seer natural e criaçom» e «ensinança». ${ }^{69} \mathrm{E}$ acrescenta: "aquelle he julgado por besta cruevel que en seus filhos he negligente». ${ }^{70}$

O enaltecimento do papel dos aios e dos mestres, surge na pena do Infante em termos que não escondem

${ }^{65}$ Vide Infante D. Pedro e Frei João Verba 1999 (ed.) cit. VB: liv. II, cap. XXI, p. 132. Esta metáfora surge, de forma recorrente, no tratado pedagógico de D. Jerónimo Osório, De regis institutione et disciplina.

${ }^{66}$ Cf. $V B$, liv. II, cap. XX: 125.

${ }^{67}$ Cf. $V B$, liv. II, cap. XXI: 132.

${ }^{68}$ Cf. $V B$, liv. II, cap. XXI: 130.

${ }^{69}$ Cf. $V B$, liv. II, cap. XV: 99-100.

${ }^{70}$ Cf. $V B$, liv. II, cap. XVIII: 115. 
a sua sensibilidade, diria mesmo a sua ternura por quem se dedica à missão de ensinar, de orientar e formar para a vida, com paciência, disponibilidade e total desinteresse. $^{71}$

A ideia de que os mestres, pela emulação, "com certos louvores» e "com bóos ensinos», «exalçam em vertudes as naturezas» ajusta-se com perfeição à ideia, essência de toda a pedagogia humanista, de que "a educação é uma segunda natureza», na expressão de Erasmo, seguidor de Plutarco. ${ }^{72}$

$\mathrm{O}$ ideal de mestre, que aflora em todos os tratados de pedagogia humanista, senão mesmo nos manuais de gramática, como no prefácio da famosa gramática do Pe. Manuel Álvares, editada inúmeras vezes, no séc. XVI, e utilizada em todos os colégios da Europa, não está ausente das páginas da Virtuosa benfeitoria.

A este propósito, é de interesse lembrar que D. Pedro, pela valor e significado que confere ao papel dos aios e mestres, afirma que a eles nunca se dará total

${ }^{71}$ Cf.VB, liv. V, cap. VIII: 285: «E os meestres, ensinando specialmente, filham muyto trabalho e nojo e, afora aquello que he demostrado juntamente a todos, dam ensinanças outras em special, e per seus castigos exalçam em vertudes as naturezas, demovendo alguns com certos louvores e amoestando outros com bóos ensinos. $\mathrm{E}$ assy spertam o entendimento preguiçosamente adormentado que lhe tiram as treevas da ignorancia e lhe fazem conhecer o claro splendor»

${ }^{72}$ Erasmo, principal representante e divulgador do pensamento pedagógico moderno - que funda as suas raízes no Quattrocento italiano - irá afirmar, cerca de um século depois de D. Pedro, que a educação é uma segunda natureza, é fonte de toda a virtude: Fons enim omnis uirtutis est diligens ac sancta educatio (Opera omnia, Leiden, 1703: LB, I. $491 \mathrm{E)}$. 
agradecimento, "porquanto nunca podemos leixar de seer obrigados a quem per natureza somos tehudos». ${ }^{73}$

Embora marcado pela discursividade medieval, O livro da virtuosa benfeitoria do Infante D. Pedro pode considerar-se pioneiro na abertura aos valores humanísticos e aos ideais pedagógicos que as obras do século XVI, com nítida influência de Plutarco, privilegiam.

No que se refere à tratadística pedagógico-politica, a presença de Plutarco é notavel, designadamente a partir de Erasmo que, na Institutio principis christiani, difunde o gosto por este género de literatura no século XVI. Nesta obra erasmiana, não é por demais sublinhar, Plutarco figura à cabeça dos autores que o príncipe deve estudar, logo depois dos textos sagrados.

É, aliás, através da síntese que Erasmo faz das ideias políticas de Plutarco, que a sua doutrina ganha vida e actualidade, nos diversos tratados humanistas.

Plutarco é com frequência citado pelos tratadistas pedagógicos portugueses de Quinhentos, sobretudo a partir de Frei António de Beja, Breve doutrina e ensinança de principes (1525). ${ }^{74} \mathrm{O}$ nome de Plutarco surge explicitamente na Doutrina de Lourenço de Cáceres ao Infante D. Luiz. ${ }^{75}$

E, além de um ou outro pormenor biográfico, referente à educação dos príncipes, que ocorre

${ }^{73}$ Cf. $V B$, liv. V, cap. II: 267.

${ }^{74}$ Frei António de Beja 1965 (ed): 22 e 119.

${ }^{75}$ Vide António Alberto de Andrade 1965: 39 e 55 
esporadicamente nas obras históricas, ou de pedagogia política, a puerilis institutio, com marcada influência dos autores clássicos, designadamente Plutarco e Quintiliano, vai ser objecto da Institutio Sebastiani Primi de Diogo de Teive - dedicada a D. Sebastião, de sete anos de idade - e do De regis institutione et disciplina (1572), o tratado sobre a instrução e a educação do rei, de D. Jerónimo Osório, dirigido ao mesmo príncipe para o educar e corrigir. ${ }^{76}$ Este tratado pedagógico do Bispo de Silves, em oito livros, o mais completo de pedagogia e de pedagogia política do nosso humanismo renascentista, e dos mais expressivos da tratadística europeia, segue de muito perto, na doutrina e nos exempla, Plutarco, no De liberis educandis, no que se refere à primeira educação e formação de bons hábitos, e tem por referência constante toda a obra deste filósofo moralista, incluindo - já que se trata de um príncipe, ou antes de um rei - a de orientação política. ${ }^{77}$

Apesar disso, no De regis institutione et disciplina, nunca é referido o nome de Plutarco que, no seu tratado De gloria, é saudado como glória e honra de Roma, sem dela ser filho. ${ }^{78}$

76 Vide Hieronymi Osori Lusitani, De regis institutione et disciplina, Olysippone, excudebat Franciscus Correa, 1572. Mais vulgarizada é a edição dos seus Opera omnia, editada pelo sobrinho e homónimo, em Roma, em 1592: Hieronymi Osori Lusitani, Episcopi Algarbiensis, Opera omnia. In unum collecta, et in Quattuor volumina distributa. Romae, MDXCII.

77 Vide Nair N. Castro Soares 1994: 297 sqq.

${ }^{78}$ No final do livro III do De Gloria (ed. cit. I. 195. 39-44), D. Jerónimo Osório não se esquece de aludir expressamente a Plutarchus Cheronaeus, \& L. Seneca, aliique permulti, que não sendo 
Assim acontece com muitos autores do nosso Renascimento que apresentam, nas suas obras, marcas indeléveis da recepção de Plutarco. O próprio Camóes leu Plutarco, com certeza, e sem o citar, colheu nele muito do saber que informa Os Lusíadas. ${ }^{79}$

Frei Heitor Pinto aponta o nome de Plutarco, repetidas vezes, ao longo da sua Imagem da vida cristá, evocando as obras em que se inspira. Nem sempre, contudo, assim acontece. No "Diálogo da Tribulação", refere vagamente a obra de Plutarco, em que se apoia, veiculando o retrato ideal do príncipe, nestes termos: «Muitos subiram a honras, que a não tiveram tanta, quando as alcançaram, como infâmia, pelos meios com que as adquiriram. Donde veio a dizer Plutarco em uma epístola ao imperador Trajano, seu discípulo, que, com razão se podia dizer feliz seu império, pois fizera obras para o merecer, e não buscara maneiras para o alcançar». ${ }^{80}$

Para Plutarco, como para os autores da sua época, que imbuídos de eclectismo filosófico recebem a influência da diatribe cínica, a imagem do governante é impregnada de misticismo. E é nesta perspectiva, comum a D. Jerónimo Osório, que Frei Heitor Pinto, sem referir

filhos de Roma, doctrinae commendatione fuerunt in eam ciuitatem accepti, atque summis honoribus ornati.

${ }^{79}$ Afirma-o A. J. da Costa Pimpão 1989: XXV, no Prefácio à edição de Os Lusíadas. São estes os termos: «E que leu [Camōes] dos prosadores? Plutarco, com certeza. Em grego? Não necessariamente, pois traduçóes, como as de Amyot para língua francesa foram verdadeiro best-seller. A elas se refere Montaigne, designando-as por «notre bréviaire».

${ }^{80}$ Frei Heitor Pinto 1952 (ed.): 263. 
a fonte, afirma, no capítulo V do Diálogo da Justiça:

O bom príncipe e prelado é um sol comum a todos, que vigia sobre seu povo com muitos olhos, estando sempre no meio como o Sol que está no meio dos sete planetas. ${ }^{81}$

Como está distante esta imagem da que servirá de lema a Luís XIV, o Rei Sol, do século seguinte!

Frei Heitor Pinto, na sua Imagem da vida cristã, faz referência explícita a tratados morais de Plutarco, tais como o De tranquilitate animi ${ }^{82}$ e os que designa em português por 'Livro do ensino e criação dos meninos' 83 e por 'Livro dos proveitos que se nos seguem de termos inimigos que nos injuriem' ${ }^{84} \mathrm{e}$ colhe muitos dos seus exempla nos Moralia e nas Vidas Paralela, citadas com frequência. ${ }^{85}$ Não fora ele o teceláo, como se autodenomina, a ajuntar a «doctrina de diversos autores, \& de muytas autoridades», para fazer a sua teia. ${ }^{86} \mathrm{Ou}$ melhor, diremos nós, o doutrinador e moralista, a manifestar a sua abundante erudição, que visa sobretudo fins didácticos.

Plutarco figura destacadamente na obra de André Rodrigues de Évora, Sentenças de diversos autores pelas quaes amoestão aos príncipes como na paz e na guerra se devem reger, dirigidas ao muito esclarecido Principe Dom

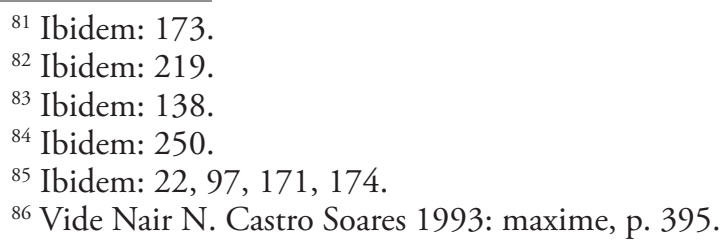


Sebastiāo, neto do mui Poderoso rei Dom João, Terceiro deste nome, nosso Senhor. ${ }^{87}$

Diogo de Teive não se esquece também de mencionar, nas suas Sententiae, "o excelente, gravissimo Plutarco" a quem deve muito da sua teorização. ${ }^{88}$

Entre nós, a literatura de sentenças, que Plutarco cultivou em obras como Regum et imperatorum apophthegmata e Apophthegmata Laconica, está bem representada desde os Prouerbia de Cataldo aos livros de Sentenças de D. Francisco de Portugal, primeiro conde de Vimioso, Diogo de Teive, Diogo Pires, André Rodrigues de Évora, Frei Luís de Granada. ${ }^{89}$

A presença de Plutarco nestas obras é notável, pela quantidade de textos representados e pelos juízos de valor que os acompanham.

Plutarco é indubitavelmente fonte inesgotável de argumentos que se repetem de autor para autor. ${ }^{90}$

Curioso é o aproveitamento que fazem de trechos ilustrativos da obra de Plutarco, as próprias oraçóes de sapiência, que se integram na pedagogia humanista

${ }^{87}$ Fac-simile do Manuscrito inédito da Casa Cadaval in Luís de Matos 1983 (ed.): 10-11; 82-83.

${ }^{88}$ Diogo de Teive 1786: 63.

${ }^{89}$ Vide Nair N. Castro Soares (1993), "A literatura de sentenças no Humanismo Português: res et uerba” cit.: 377-410.

90 Servem de exemplo, além fronteiras, as já referidas obras escritas para a educação de um príncipe menino ou de um rei no exercício do poder, tais como a Institution du prince de Guillaume Budé, o Livro de Marco Aurélio de Frei António de Guevara; entre nós, o Libro primero del principe christiano de Francisco de Monçon; a Institutio principis, precedia de uma colectânea de Sententiae de Diogo de Teive e o De regis institutione et disciplina, de D. Jerónimo Osório, dedicados ao mesmo rei D. Sebastião. 
e enunciam a sua ratio studiorum. Está neste caso a Omnium Philosophiae partium laudibus et studiis, 'sobre o estudo e louvor de todas as partes da Filosofia', de Hilário Moreira, 'proferida na Universidade de Coimbra, a mais próspera de todo o mundo, segundo o costume da Academia, em 1 de Outubro do ano do Senhor de 1552', como se lê no frontispício da edição de Coimbra dos tipógrafos régios João Barreira e João Álvares, saída a lume no mesmo ano em que fora apresentada. ${ }^{91}$ A iniciar esta oração, figura um longo passo, que contém o elogio das letras, do De liberis educandis, 10, em tradução latina, colhida na Miscelania Velasci de $1473 .^{92}$

Reveladores da importância e significado da mensagem de Plutarco, na construção do discurso quinhentista, são o Diálogo da viciosa vergonha de João de Barros. ${ }^{93}$ e o Colloquium de Luisa Sigeia, um diálogo sobre a vida contemplativa, em contraste com a vida áulica, a vida activa. Nesta obra, Plutarco está

${ }^{91}$ Hilarii Moreirae Conimbricensis ad inuictissimum Lusitaniae Regem D. Joannem tertium de omnium Philosophiae partium laudibus, et studiis oratio. Apud inclytum Conimbricense lyceum universi terrarum orbis florentissimum de more Academiae habita Calend. Octob. Anno Salutis M. D. LII. Conimbricae, Joannes Barrerius et Joannes Alvarus Reggi Typographi excudebant.

${ }_{92}$ Vide Albino A. Matos 1990: 48-49 e 93.

93 O Diálogo da viciosa vergonha, inspirado no tratado de Plutarco, Peri dôsopias segundo afirma Barros (cf. fol. A ij vo da edição princeps de 1540), in Maria Leonor Carvalhão Buescu 1971. Sobre a inspiração de Barros na tradução de Erasmo desta obra de Plutarco, e não no original grego, vide Américo da Costa Ramalho 1986: 275-280. 
representado, em profusão, com trechos de muitas das suas obras, na lingua original. ${ }^{4}$

Também António Luís, um humanista da primeira metade do século XVI, comentador de Galeno e Aristóteles e crítico de Erasmo, demonstra conhecer e apreciar o autor de Queroneia. Não só no tratado De pudore sobre a mesma matéria do Diálogo da Viciosa Vergonha - que dedica a João de Barros -, mas também nos Problemmata. ${ }^{95}$

Entre as fontes apontadas por António Luís para este tratado científico - que, no seu título, é designado de opus absolutum, et facundum, et uarium, multiingaque eruditione refertissimum, 'obra completa e eloquente, cheia de multifacetada erudição' - encontra-se Plutarco, que é citado em vários dos seus tratados. ${ }^{96}$

De grande voga no Renascimento são as obras que se ocupam das biografias de homens ilustres, a que dão o tom as Vidas Paralelas de Plutarco. A atitude epistemológica de Plutarco na seriação e apresentação

${ }^{94}$ Sobre o Colloquium de Luísa Sigeia, vide em Odette Sauvage 1970. Cf. as múltiplas citaçóes de Plutarco, e. g.: 34; 37; 114-120.

95 Antonii Lodouici medici olyssipponensis Problematum libri quinque opus absolutum, et facundum, et uarium, multiiugaque eruditione refertissimum, Olyssipone, M. D. XXXIX. Esta obra foi parcialmente estudada, em tese de mestrado orientada pelo Prof. Costa Ramalho, por Manuel Chaves de Andrade 1995.

${ }^{96}$ Vide Ad lectorem praefatio auctoris, onde confessa ter seguido, na preparação da sua obra, os autores gregos, sobretudo estes: Galeno, Próculo, Plutarco, Platão, Aristóteles, Alcino, Alexandre, o divino Dioniso e inúmeros outros» Entre as obras de Plutarco que cita, figuram os Apophthegmata, o tratado intitulado Maxime cum principibus uiris philosopho esse disserendum e os Coniugalia praecepta. 
dos factos, em ordem à dignidade que imprime às Vidas dos seus varôes, vai ao encontro do espírito humanista, com raízes em Petrarca e Lorenzo Valla, que subordinam a cultura à moral. Assim, no prefácio do De uiris illustribus, que inicia o género, Petrarca acentua o valor paradigmático da obra, como guia de conduta.

Significativa é também, neste sentido, a Vida do Infante D. Duarte. de André de Resende, dirigida ao Senhor Dom Duarte, duque de Guimarães, seu filho. O humanista eborense, apreciador de Plutarco - como o revela a sua oração de sapiência de 1551 , onde se lhe refere como escritor da maior autoridade, Plutarchus grauis cum primis auctor -, conclui nestes termos a sua biografia: "Esta é a lição, Excelente Senhor, que desejei de ler, da qual confio eu que V. Excellencia poderá tirar documento, de que muito se aproveita, se frequentemente a ler, e fizer a sua lembrança familiar». ${ }^{97}$

A própria História, no Renascimento, herdeira da concepção de Cícero em De oratore (2. 9. 36), ${ }^{98}$ muito deve à obra de Plutarco, que tratou paradigmaticamente a história dos seus varóes ilustres, gregos e romanos, impondo-os como modelos de comportamento ético, cívico e político, que a tradição literária veiculou. ${ }^{99}$ Exemplar, neste domínio, é a Historiografia Portuguesa, designadamente a obra de João de Barros. ${ }^{100}$

${ }^{97}$ Vide José Pereira Tavares 1963: 132.

${ }^{98}$ São estes os termos ciceronianos: Historia uero testis temporum, lux ueritatis, uita memoriae, magistra uitae, nuntia uetustatis.

${ }^{99}$ Vide John Dillon 1977: 233-240.

${ }^{100}$ Vide Nair N. Castro Soares 2002: 15-37. 
A poesia quinhentista indicia também a influência de Plutarco: André Falcão de Resende, na "Epístola I: a Heitor da Silveira, seu cunhado, estando na Índia", escreve: «A Sparta que alcancei de Deus com tudo,/minha consorte digo, amo e acompanho». Esta expresssão figurada, que se tornou proverbial, encontra-se nos Moralia e também nos Adagia de Erasmo, como provou o Prof. Costa Ramalho. ${ }^{101}$

Ainda a propósito de expressôes sentenciosas, um dos Ditos portugueses dignos de memória, editados pelo Prof. Hermano Saraiva, refere-se a uma resposta, um salse dictum, de D. Jorge, filho bastardo de D. João II, dada a um parente seu, que o interpelava sobre o casamento que ele queria contrair com uma rapariga nobre, muitos anos mais nova do que ele, sendo nisso contrariado pelos filhos, sobretudo pelo mais velho, D. João de Lencastre, duque de Aveiro. A resposta de D. Jorge, o discípulo de Cataldo, é a mesma de Catão o Antigo, confrontado com situação semelhante, que figura nas Vidas Paralelas de Plutarco. ${ }^{102}$

${ }^{101} \mathrm{Na}$ origem desta expressão figurada, contida nestes dois versos, está um passo da tragédia euripidiana Télefo, que, perdida a ligaçáo com o texto original, se tornou provérbio, a significar genericamente: "aceita o que te coube em sorte e estima-o», "da sorte que tiveste, não te queixes, mas tira dela o possível partido».

Este provérbio surge em dois trechos dos Moralia de Plutarco, bem acessíveis aos leitores do século XVI: no De Tranquillitate animi e no De exilio; figura em Adagiorum opus de Erasmo, que sobre ele disserta longamente. Segundo o Humanista de Roterdão, este provérbio tem diversas aplicaçóes: "por exemplo, quando aconselharmos alguém a que desempenhe com decoro o papel que assumiu». E explicita Erasmo: «É marido cumpra as obrigaçóes de marido». Vide Américo da Costa Ramalho 2000: 172-176.

${ }^{102} \mathrm{~A}$ resposta, cheia de ironia, de $\mathrm{D}$. Jorge é que queria casar 
Por tudo o que ficou dito um facto pode ser constatado: a influência de Plutarco no Humanismo, em Portugal, não é resultado do manuseio de colectâneas, em grande voga na época, de que são exemplo as de Ravisius Textor, Gregorius Reish, Niccolò Perotti. ${ }^{103}$

Pelo contrário, Plutarco, é lido e assimilado, no original, em tradução latina e em vulgar e, com a sua mensagem, informa a própria mundividência da época, no que se refere à educação e formação do homem e do príncipe, à teorização ético-política, ao relacionamento em família e em comunidade, às formas de comportamento humano, nas diversas circunstâncias.

A influência de Plutarco determina mesmo, muitas vezes, uma nova forma de mentalidade, uma nova atitude cultural, que passa pela reflexão sobre temas e motivos, em que se implicam e interpenetram parâmetros de carácter ontológico ou comportamental, do domínio da moral e da psicologia individual ou social, até então latentes, que se revigoram e actualizam através da mensagem de Plutarco.

Por último, um apontamento apenas sobre as ideias estéticas que se impuseram no Renascimento e se prendem com a recepção de Plutarco. Esta não se concretiza apenas como elemento informador da inuentio, da res inventiva, dos autores quinhentistas, mas

«Por ver se podia haver outros filhos tão virtuosos como os que já tenho». Vide A. Costa Ramalho 1998: 128-129.

${ }^{103}$ Vide Nair N. Castro Soares 1994: 226-228; Idem 1993 : 377-410. 
também, e de modo decisivo, na definição do estilo, da elegantia da latinitas.

A revitalização da retórica helenística e a reflexão sobre a obra de Plutarco, designadamente sobre a Vida de Cícero, vertida para latim por Leonardo Bruni Aretino, contribui para que se imponha a primazia do êthos, instância de enunciação centrada no eu, que privilegia, em nome da autenticidade, a presença do indivíduo na escrita

Nesta Vita Ciceronis, sobretudo na comparaçáo que estabelece, no seu final, entre Cícero e Demóstenes, favorável ao orador grego, resume Plutarco o seu ideal de estilo, em que o primado da energia moral e da acção se sobrepóe à retórica da palavra.

Neste sentido se orienta também o pensamento de Séneca, que, numa das suas cartas a Lucílio (14. 90. 20 ), previne o discípulo de que «o fascínio das palavras consegue desviar da verdade até mesmo os grandes espíritos». ${ }^{104}$

Esta retórica do êthos, que póe em relevo a força expressiva, a emphasis, do apotegma, do adágio, do provérbio, da sententia, em que se interpenetram concisão e propriedade, teve um papel preponderante na reflexão crítica da arte da palavra no Renascimento, designadamente na pedagogia de Erasmo, que exerceu marcada influência, entre nós, em pedagogos e mestres de retórica como Jerónimo Cardoso, Clenardo, João Vaseu, João Fernandes.

${ }^{104}$ Vide Lúcio Aneu Séneca 1991 (ed.): 445. 
A literatura de sentenças, de que Plutarco, com os seus Apophtegmata, é um lídimo representante e fonte privilegiada dos humanistas, assume, como observámos, uma importância singular, em Portugal e em toda a Europa do Renascimento.

Além de colectâneas de apotegmas, a produção dramática quinhentista reflecte o seu manuseio e memorização. Servem de exemplo os autos de Camóes e sobretudo as comédias de Jorge Ferreira de Vasconcelos.

Eugenio Asensio, no magistral estudo que abre a sua edição da Comédia Eufrosina considera-a "Un profuso repertorio de ejemplos y sentencias morales». E, a este propósito, acrescenta: «Los héroes y la sabeduría antigua penetraban en el mundo renacentista llevados por Plutarco y los textos de clase». ${ }^{105}$

Além da Eufrosina também a Aulegrafia entretece o seu discurso de apotegmas e provérbios, que, destacados no final da edição, ocupam várias páginas ${ }^{106}$ — a provar o gosto pela expressão sentenciosa, lapidar, que Plutarco privilegia.

Em suma, Plutarco exaltou o valor da virtude e apresentou a forma de a pôr em prática, serviu de modelo estético, no seu gosto pela breuiloquentia, e foi um dos autores mais lidos e imitados no século XVI.

${ }^{105}$ Vide Jorge Ferreira de Vasconcelos 1951(ed.): XI e XX, respectivamente.

${ }^{106}$ Note-se que a linguagem da comédia, que procura adequar-se ao êthos das personagens de baixa condição social, do vulgo ignaro, aos seus gostos e maneiras, reflecte, como nenhum outro género, as tendências e marcas expressivas próprias do tempo e exprime o gosto pela expressão sentenciosa. 
Defensor e representante de uma nova ordem social, Plutarco, com a sua mensagem - herança do pensamento grego dos séculos V e IV a. C., assimilada com eclectismo e apurada sensibilidade -, soube impor uma nova mentalidade, um novo estilo de vida.

Para se ajuizar do significado e relevância da sua obra, bastaria para tanto recordar as suas ideias sobre a educação do príncipe e do homem comum, precursoras da moderna psicologia diferencial; a importância da afectividade entre os esposos e entre pais e filhos; a obrigação moral dos pais investirem na educação daqueles que geram; o papel da mãe, a relação umbilical entre mãe e filho e a defesa do aleitamento materno; o casamento e as regras do bom viver matrimonial; o proveito que advém do convívio, em família, das pessoas idosas, que acumulam saber e experiência e se tornam pilares dos valores essenciais da vida. Enfim, a crença na perfectibilidade do homem, na cultura como instrumento de virtude e de uita beata.

Este ideal humano que é assimilado pelos autores mais representativos do Renascimento, tornou-se património da humanidade e conferiu a Plutarco, na distância de dezanove séculos, um lugar entre nós. 